Administration

\title{
Holiday Effect on Traffic Fatalities
}


Technical Report Documentotion Page

\begin{tabular}{|c|c|}
\hline $\begin{array}{l}\text { Report No. } \\
\text { DOT HS-807 } 115\end{array}$ & 3. Recipient's Cotalog No. \\
\hline 4. Title and Subtitle & $\begin{array}{l}\text { 5. Report Date } \\
\text { Apr11 } 1987\end{array}$ \\
\hline Holiday Effect on Traffic Fatalities & $\begin{array}{l}\text { 6. Performing Orgonizotion Code } \\
\text { IHITSA, NCSA, NRD } 31\end{array}$ \\
\hline $\begin{array}{l}\text { 7. Author!s) } \\
\text { Robert Arnold and Ezio C. Cerrelli }\end{array}$ & 8. Performing Organization Report No. \\
\hline \multirow[t]{2}{*}{$\begin{array}{l}\text { 9. Porforming Organizotion Nome and Address } \\
\text { National Center for Statistics and Analysis } \\
\text { Mathematical Analysis Division } \\
4007 \text { th St. S.W. } \\
\text { Washington, DC } 20590\end{array}$} & \begin{tabular}{|l} 
10. Work Unit No. (TRAIS) \\
11. Contract or Gront No.
\end{tabular} \\
\hline & \multirow{2}{*}{$\begin{array}{l}\text { 13. Type of Report and Period Covered } \\
\text { Technical Report }\end{array}$} \\
\hline \multirow{2}{*}{$\begin{array}{l}\text { 12. Sponsoring Agency Nome ond Address } \\
\text { U.S. Department of Transportation } \\
\text { National Highway Traffic Safety Administration } \\
\text { Washington, DC } 20590\end{array}$} & \\
\hline & $\begin{array}{l}\text { 14. Sponsoring Agency Code } \\
\text { NHTSA, NCSA, NRD } 31\end{array}$ \\
\hline
\end{tabular}

15. Supplementary Notes

16. Abstroct

The report identifies those holidays that show an increase in traffic fatalities and estimates the size of this increase for each national holiday.

A procedure is presented that can be used to forecast the expected fatality count for each upcoming holiday period.

\begin{tabular}{|l|l|l|l|}
\hline $\begin{array}{l}\text { 17. Kay Words } \\
\text { Traffic fatalities, Holidays, } \\
\text { Forecast, Trends }\end{array}$ & $\begin{array}{l}\text { 18. Distribution Stotement } \\
\text { Document is available to the public } \\
\text { through the National Technical Infor- } \\
\text { mation Service, Springfield, VA. 22161 }\end{array}$ \\
\hline $\begin{array}{l}\text { 19. Security Clossif. (ol this report) } \\
\text { Unclassified }\end{array}$ & $\begin{array}{c}\text { 20. Security Clossif. (of this poge) } \\
\text { Unclassified }\end{array}$ & $\begin{array}{c}\text { 21. No. of Poges } \\
22\end{array}$ & 22. Price \\
\hline
\end{tabular}

Form DOT F $1700.7(8-72)$

Roproduction of complesed page authorized 
HOLIDAY EEEECI ON IBAEEIC EATALIIIES

\section{Introduction}

During holiday periods there is, in general, an increase in the number of people that are killed on the highways, perhaps due to increases in travel and changes in travel patterns.

This paper identifies those holidays that show an increase in traffic fatalities and estimates the size of this increase for each national holiday. No attempt is made to explain the reasons for these increases. A procedure is presented that can be used to forecast the expected fatality count for each upconing holiday period.

\section{Procedure}

The objective is to determine if and by how much the number of traffic fatalities increases during each specific holiday. It requires the adoption of a reference level fron which change can be measured. To establish this reference levei it is necessary to take into account some basic factors governing the size of the traffic fatality toll. The overall annual traffic fatality count varies considerably, due to changes in travel, safety prograns, national econony, and many other factors. From 1975 to 1985 , annual traffic fatalities ranged from a low of 42,589 in 1983 to a high of 51,093 in 1979 , a difference of 20 percent. Figure 1 shows the annual trend in traffic fatalities during the 1975-1985 period. In addition, the number of traffic fatalities shows a large variation over the 12 nonths of the year, and an even stronger variation during the days of the week. January produces the fewest daily fatalities, an average of 97 each day over the 11-year period. This daily average rises steadily during the spring and summer months to a peak of 148 fatalities per day in August, then drops to 128 per day in December. Figure 2 presents these daily averages, over the 11 year period, for the 12 months of the year. Looking at the weekly pattern, Tuesdays have the lowest average count, 97 per day, as compared to Saturdays with an average count of 188 per day. Figure 3 show this weekly pattern. Finally, this weekly pattern is different for different months. Weekend traffic fatality counts have a stronger monthly variation than weekday counts. Figure 4 shows how these daily counts vary. In this figure all weekdays have been grouped together since they show a sinilar pattern.

The reference level adopted in this paper takes into account all the information presented in Figures 1 through 4 and consists of the average fatality count, over the 11 year period, for each day of the week in each month. The 84 average counts $(7 \times 12)$, thus obtained, represent the typical fatality counts from which the holiday effects are neasured. Table A lists these base values, which are also plotted in figure 5. 


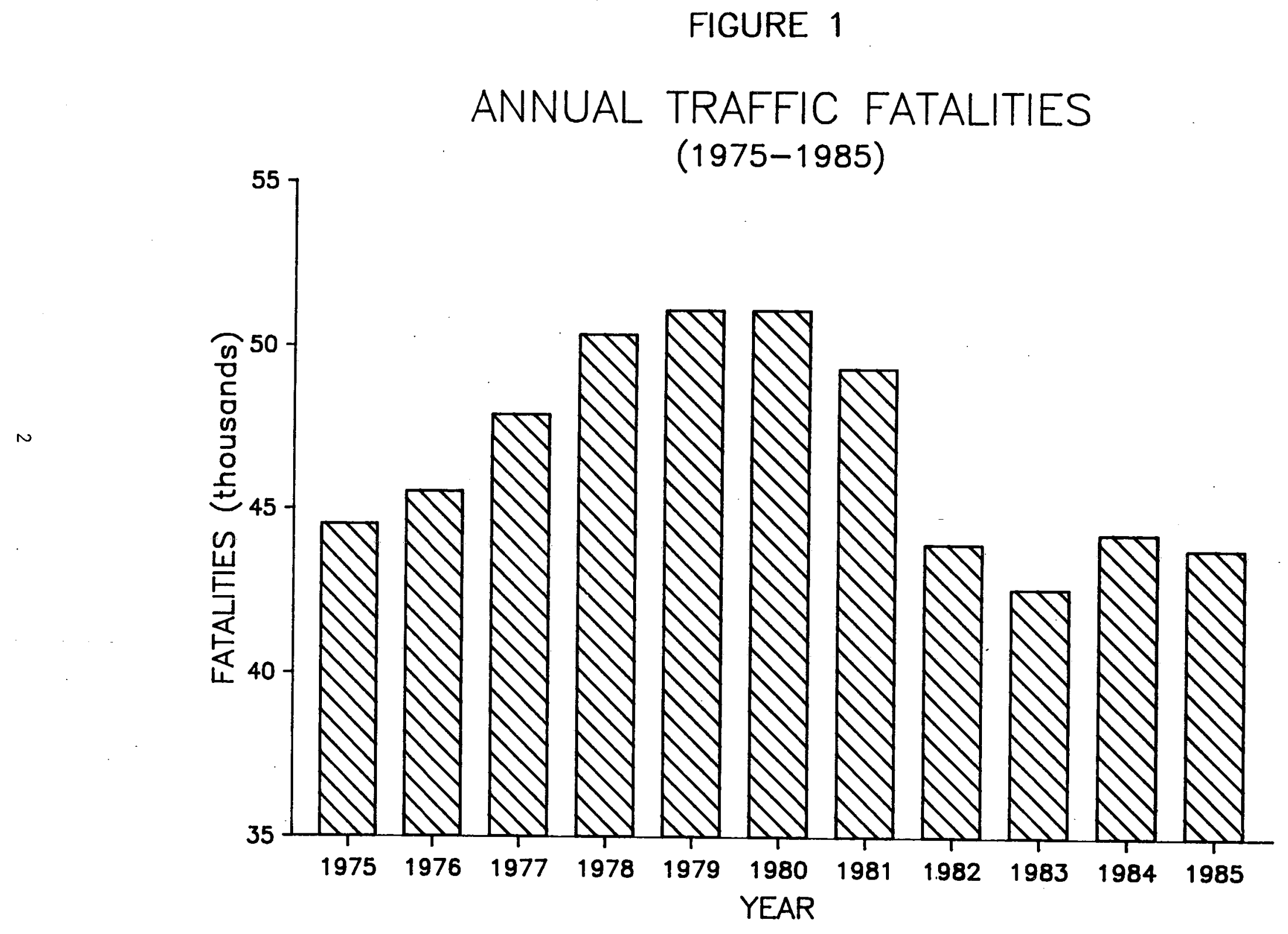


FIGURE 2

\section{AVERAGE NUMBER OF FATALITIES/DAY \\ (1975-1985)}

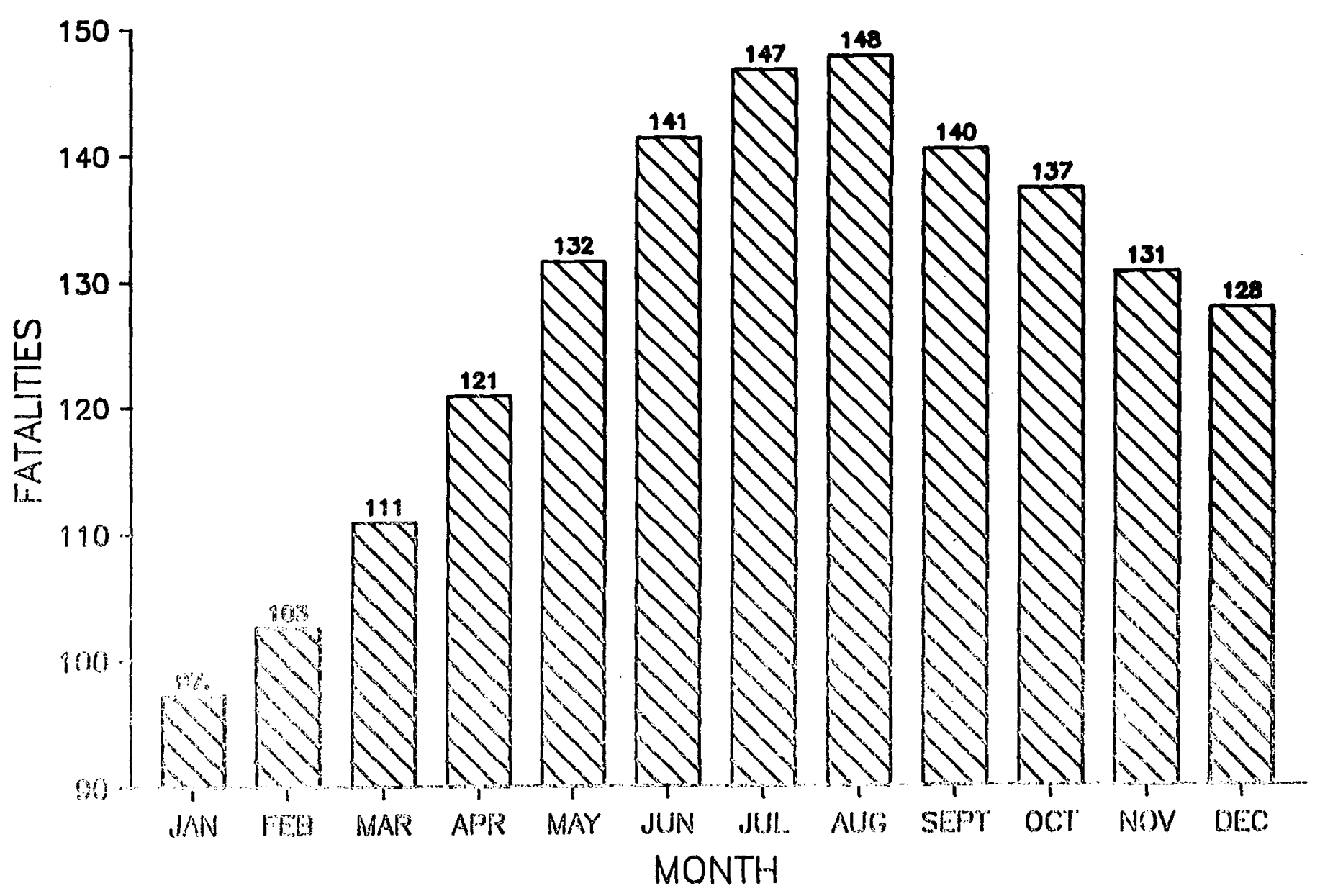


FIGURE 3

\section{AVERAGE WEEKLY FATALITIES (1975-1985)}

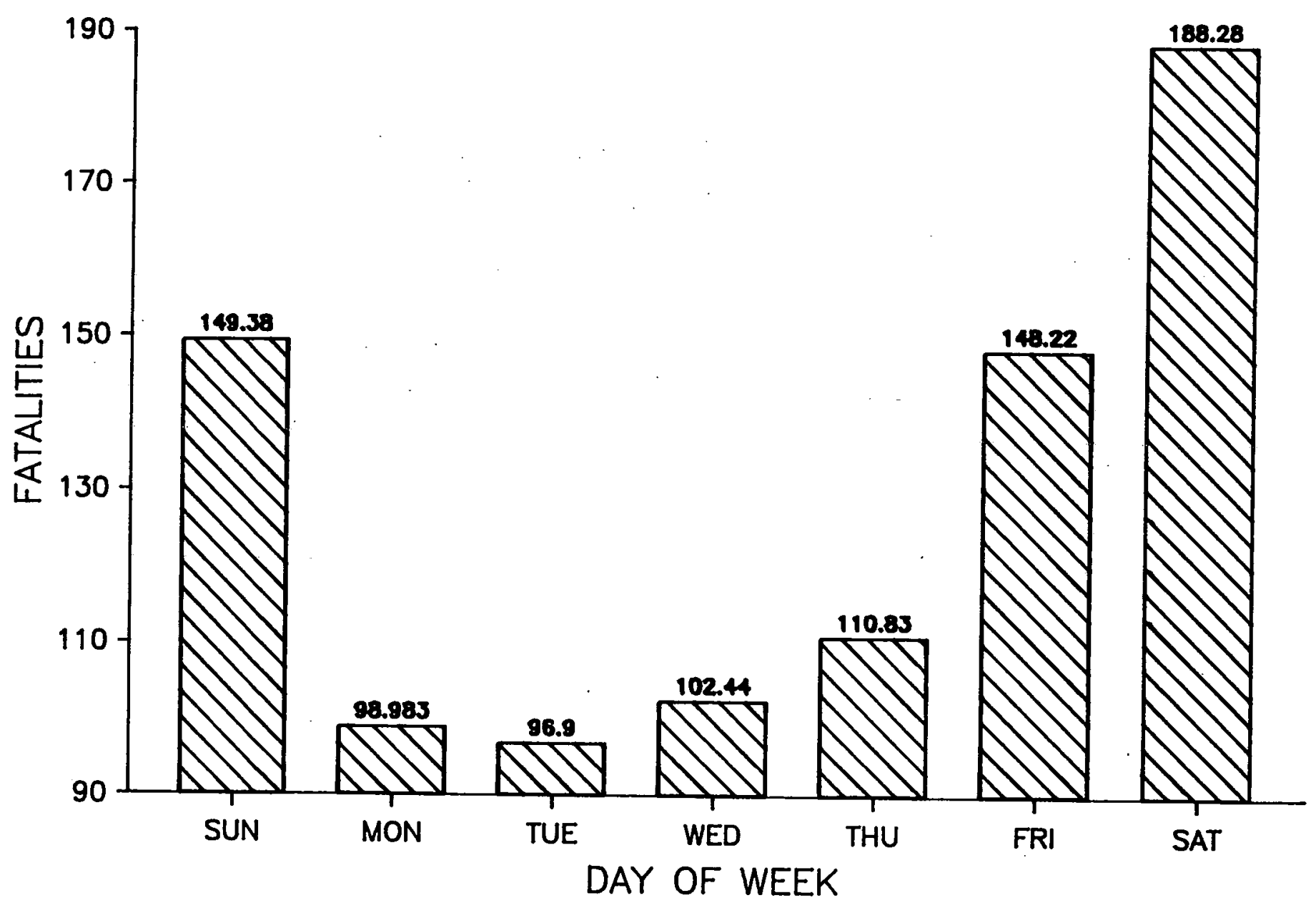


FIGURE 4

\section{ANNUAL FATALITY CYCLE BY DAY OF WEEK} (RELATIVE TO JANUARY)

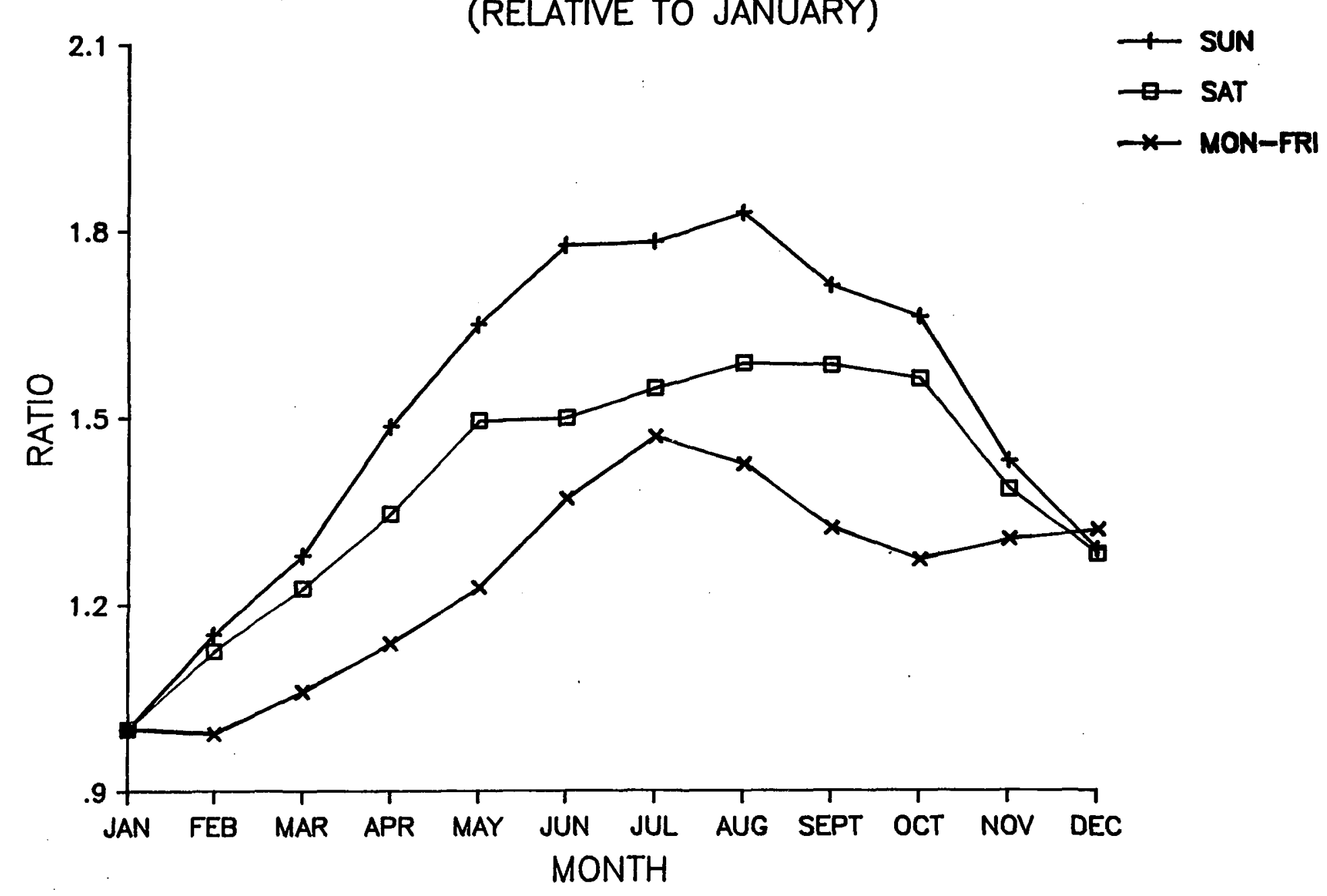


FIGURE 5

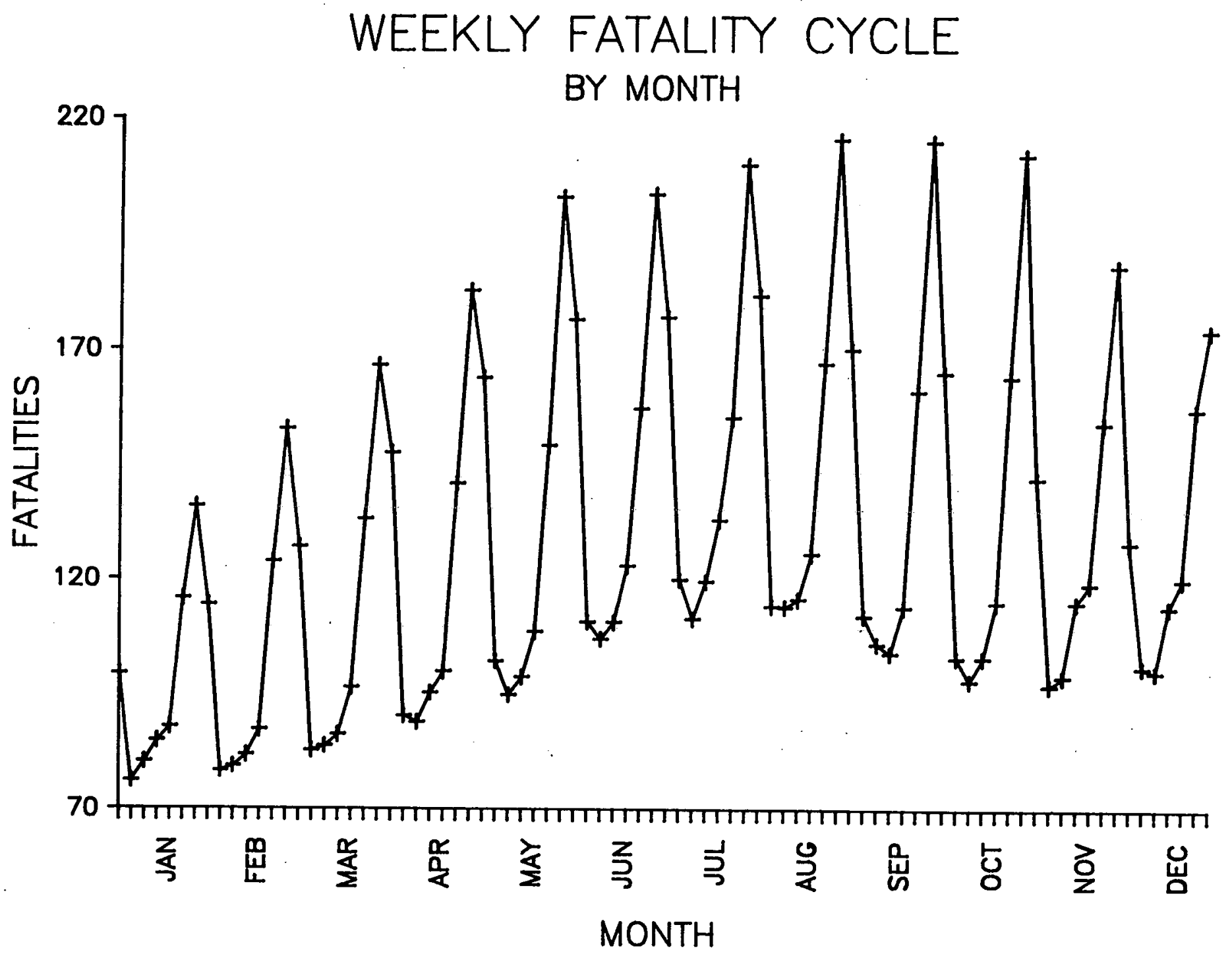


Table A

Average Fatality Counts by Month and Day of Week

\begin{tabular}{lcccccccc} 
& \multicolumn{8}{c}{ Day of Week } \\
January & Sunday & Monday & Tuesday & Wednesday & Thursday & Friday & Saturday \\
February & 114 & 76 & 80 & 85 & 88 & 116 & 136 \\
Mareh & 127 & 78 & 79 & 82 & 87 & 124 & 153 \\
April & 148 & 90 & 84 & 86 & 96 & 133 & 167 \\
May & 164 & 102 & 89 & 95 & 100 & 141 & 183 \\
June & 177 & 111 & 107 & 111 & 123 & 149 & 203 \\
July & 177 & 120 & 111 & 120 & 133 & 155 & 210 \\
August & 182 & 114 & 114 & 116 & 126 & 167 & 216 \\
September & 170 & 112 & 106 & 104 & 11.4 & 161 & 215 \\
October & 165 & 103 & 98 & 103 & 115 & 164 & 212 \\
Novenber & 142 & 97 & 99 & 115 & 119 & 154 & 188 \\
Decenber & 128 & 101 & 100 & 114 & 121 & 157 & 174
\end{tabular}

The table above gives the average number of fatalities occurring in the 84 typical days of the year over the 1975-1985 period. By comparing the actual average nuaber of fatalities observed during the 11-year period for a given day to the average shown in the table for the corresponding typical day, a standard index can be obtained which measures the relative change. The following examples will aake the procedure more clear. First, note that, the national holidays are divided into two groups: al those that fall on the sane calendar day, and b) those that fall on the same day of the week. In the first group are New Year's, Independence Day, Veterans' Day and Christmas, while in the second group are Martin Luther King Jr. and George Washington birthdays, Memorial Day, Labor Day, Columbus Day and Thanksgiving.

The procedure for developing the index is slightly different for the two groups. For holidays in the second group the procedure for estimating the holiday effect is based on the percent change between the actual average number of fatalities for the 11 holidays on file and the appropriate count presented in Table A. This change is then inflated by a factor of 1.4 to account for the fact that these holiday counts were also used in computing the averages in Table A. Thanksgiving Day is an example. The expected average number of traffic fatalities for a Thursday in Novenber, over the 11-year period, is shown in the table in the Thursday colunn and the Novenber line. The value of 119 in this cell represents the average number of fatalities which would have occurred, if Thanksgiving had been a typical Thursday in November during the 1975-1985 period. The actual average number of fatalities during all Thanksgiving Days in that period was 135 fatalities per holiday. The percent change between 135 and 119 is $13.4 \%$. When multiplied by 1.4 the change becomes $18.8 \%$, which measures the difference between a typical Thanksgiving Day count and the count for a typical non-holiday Thursday in Novenber. 
For the holidays in the first group, the procedure for obtaining the expected average value is more complex since they fall on a different day of the week each year. For these holidays, the expected average count is obtained by identifying the number of times the holiday occurred in each day of the week during the 11-year period, extracting the corresponding values from the table, and calculating the average of these 11 counts. The actual average and the index is produced in the same way as for holidays in the second group.

\section{Results}

Figures 6 through 14 and the associated discussion summarize the results of the study and offer some interpretation of the findings. All ratios shown in the figures have an expected value of 100 , with deviations greater than $10 \%$ considered statistically significant.

Figure 6, 7 , and 8 are associated with holidays which fall on the same calendar day, while figures 9 through 14 refer to those holidays falling on specific days of the week.

\section{Discussion of Figures}

Fiqure 6. Day of Year is defined to include February 29 as Day 60 so March 1 is always Day 61 and December 31 is always Day 366 , leap year or not. The vertical grid lines separate the months. Day 60 has only three occurrences in the period 1975-1985; all other Days occur. 11 times. Each weekday occurs exactly 574 times in this period. Occurrences of weekday-month combinations vary from 44 to 49 . The expected average number of fatalities for a specific day of the year is the average of the counts in Table A for the weekdays on which that day occurred during the 1975-1985 period. The values plotted in Figure b are the observed average number of fatalities normalized against the expected average number for each day of the year. Most of the points have values between 90 and 110 . The seven highest points, January 1 , July 3 and 4 , and December 21 through 24 , appear to be outliers. December $26,28,29$, and 30 , tagether with Novenber 30 , are outliers on the low side. The remaining 354 points have a standard deviation of 4.5 . The grid lines at 90 and 110 are about 2.2 of these standard deviations fron 100. The seven high values, and the low ones near the end of the year, are examined in more detail in figures 7 and 8. In Figure 6 there is a hint of high values at the end of May, near Memorial Day, and at the beginning of September, near Labor Day. There is no notice of the presence of Thanksgiving in this figure. These three holidays are on particular weekdays and should not show up well on this plot because they they are spread over up to seven different days of the year. They are examined in Figures 9 through 11.

Fiqure 7. The Decenber through February sequence is shown in a single figure to avoid separating the Christmas-New Year holiday season. January 1 thus becomes Day 367. Vertical grids separate months. The standard errors, shown as the half-lengths of the vertical bars, represent sampling errors and are calculated separately for each day. Over the whole year they range from 2.1\% of the normalized value for July 4 (the highest 
absolute, not normalized, number of fatalities) to $3.3 \%$ for January 2 (the lowest number). February 29 is a special case. It has a higher average than does January 2 but, with only 3 occurrences, it has a 5 mall sample and its calculated standard error is $5.2 \%$. Other than this one, these sampling errors are

smaller than the $4.5 \%$ standard deviation calculated as described above for Figure 6. Since the nornalization is with respect to the month within which the day occurs, a series of high values, like those at 21 through 24 Decenber, will cause a noticeable depression of the rest of the month to keep the average near 100 . This is seen in the first two weeks in December. Christmas Day and the 5 days after it are still lower. They are not only lower than the grand mean of 100 but are lower than "normal" if the first two weeks of the month are considered "normal " for Decenber. New Year's Eve is much lower on this plot than New Year's Day. The former has been normalized against December, the latter against January. January fatalities have averaged about $25 \%$ lower than December fatalities during this period.

Eiqure 8. July 3 is clearly above normal; July 5 is.clearly not. Independence Day was celebrated on July 4 in eight out of eleven years, July 5 in 1976 and 1982 , and July 3 in 1981 .

Fiqure 9. Since Menorial Day occurs always on Monday and varies between May 25 and May 31 , its effect is scattered on a day of year plot like Figure 6. Figure 9 shows the 30 days before and after the holiday. The value for the holiday is about 123 and no other day in this period is outside the 90-110 grid lines. A very large value for the holiday would noticeably depress Mondays in the "before" period because it is normalized against them alone. On average they should go down about one third as much as the holiday goes up. This may be happening on the Monday before the holiday, day -7 on the plot, but the magnitude is too 5 mall to separate confidently from the random variation.

Fiqure 10. Labor Day, another always-Monday holiday, is shown in Figure 10. Its value is about 125 . The day after, at about 112, verges on being significant but could easily be on the tail of the distribution of ordinary days about 100 . We may be seeing here the depress-ather-Mondays effect. Note that days $+7,+14$, and +21 (these are always Mondays in september: +28 is not necessarily sol are consistently low.

Fiqure 11. Thanksgiving, an always-Thursday holiday, shows several interesting features. The day itself is at 114 , above the noise, but barely. It is the day before that is high, with a value of about 130 . This day is Wednesday and a depressed Wednesday effect may be showing at -8 and -15 . The unusually low values immediately after the holiday show some similarity to the after-Christmas effect noted earlier. The very high values at +26 through +29 are because these days contain contributions from the high values at 21 through 24 December.

Fiqure 12. During 1975-85 the third Monday in February has been a federal holiday and has been widely celebrated as George Washington's Birthday. The plot of this day in Figure 12 shows no features. The day itself is slightly below average but not significantly so. 
FIGURE 6

Normalized Daily Fatalities

Averaged over 1975-1985

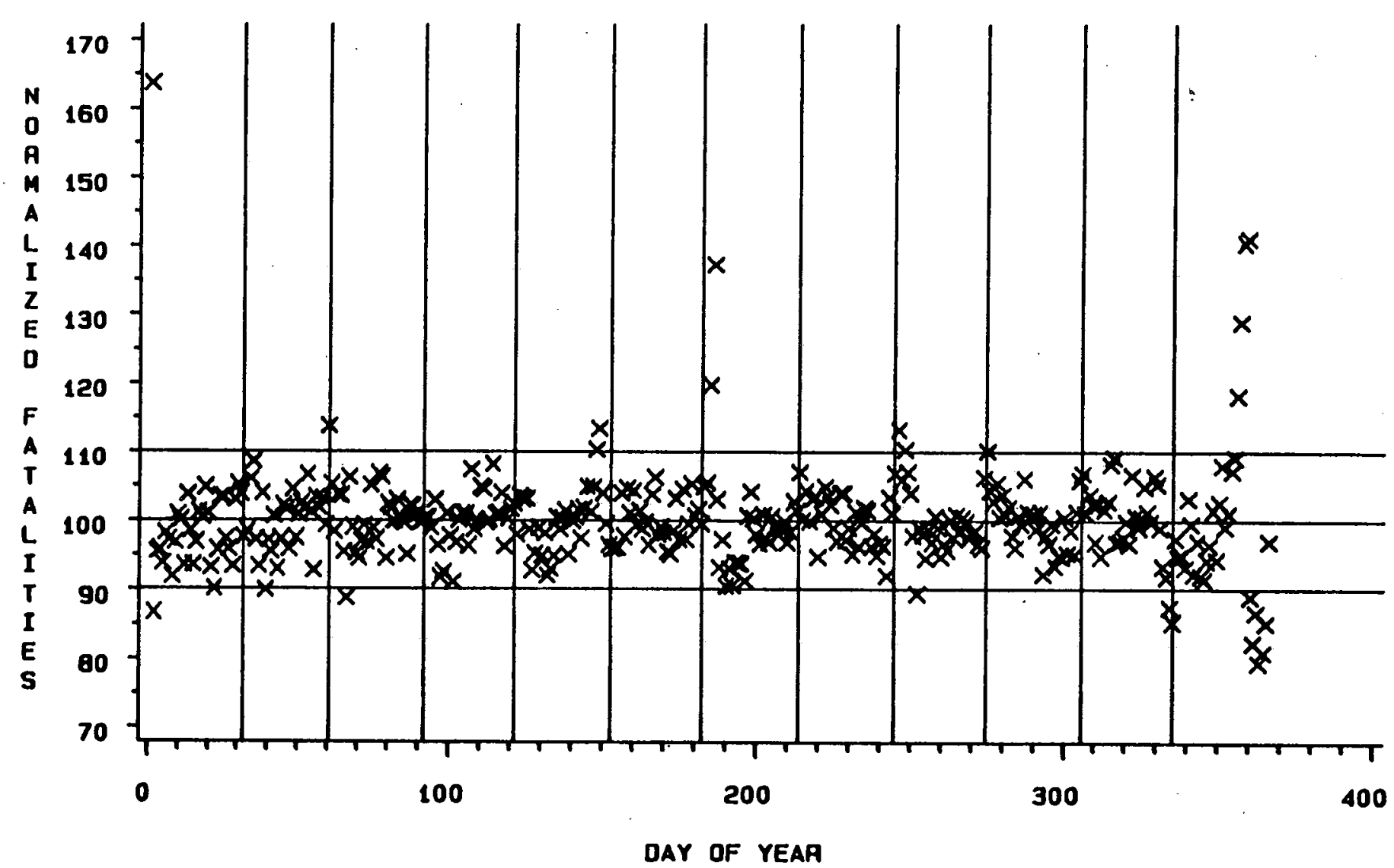




\section{FIGURE 7}

\section{Normalized Daily Fatalities}

in December, January, and February

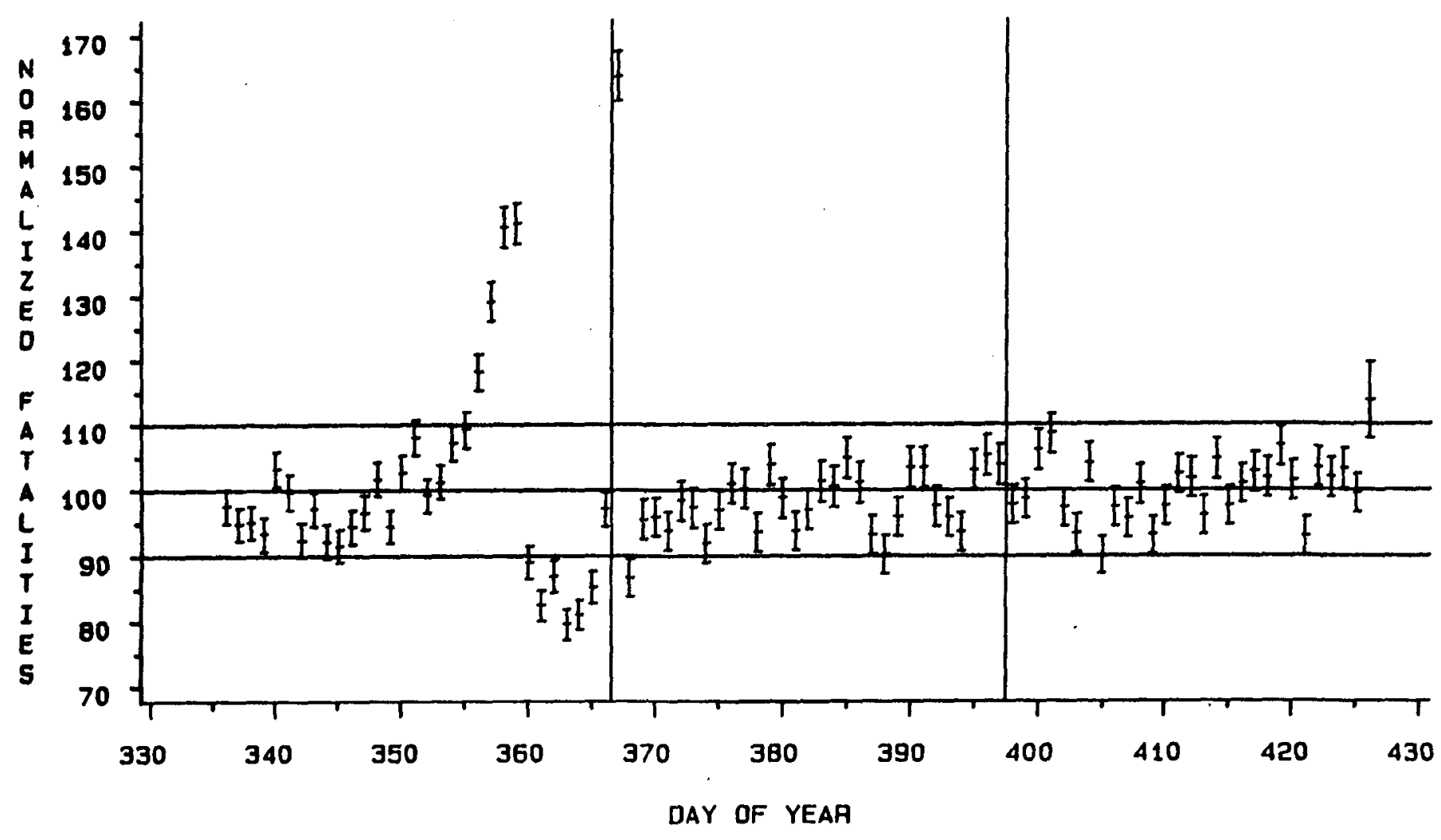

gAF LENGTH IS 2 STANDARD ERRORS 
FIGURE 8

\section{Normalized Daily Fatalities \\ in June and July}

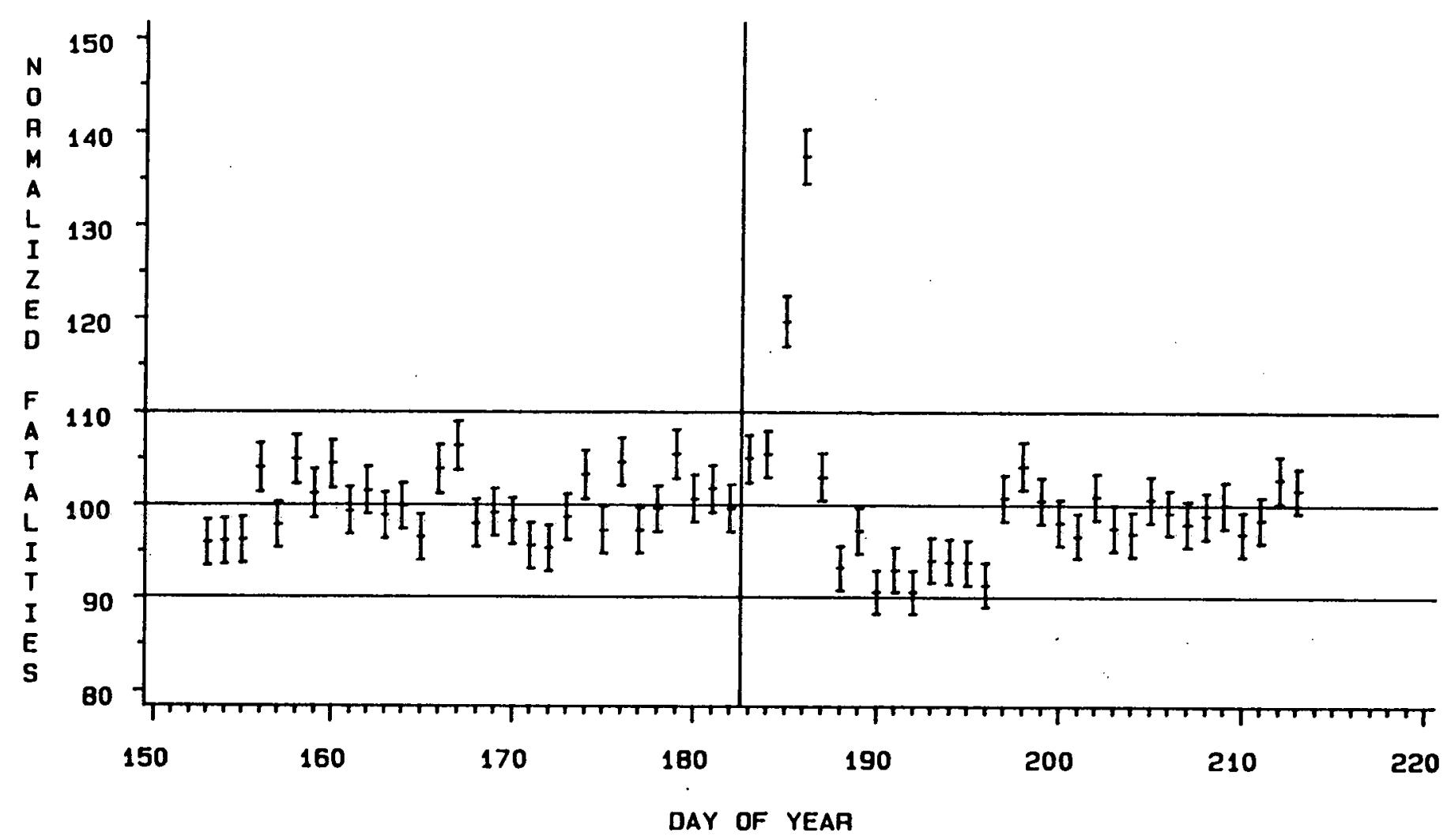

BAR LENGTH IS 2 STANDARD ERRORS 


\section{FIGURE 9}

\section{Normalized Fatalities Near Memorial Day Averaged over 1975-85}



BAA LENGTH IS 2 STANDARD EARORS 
FIGURE 10

Normalized Fatalities Near Labor Day Averaged over 1975-85

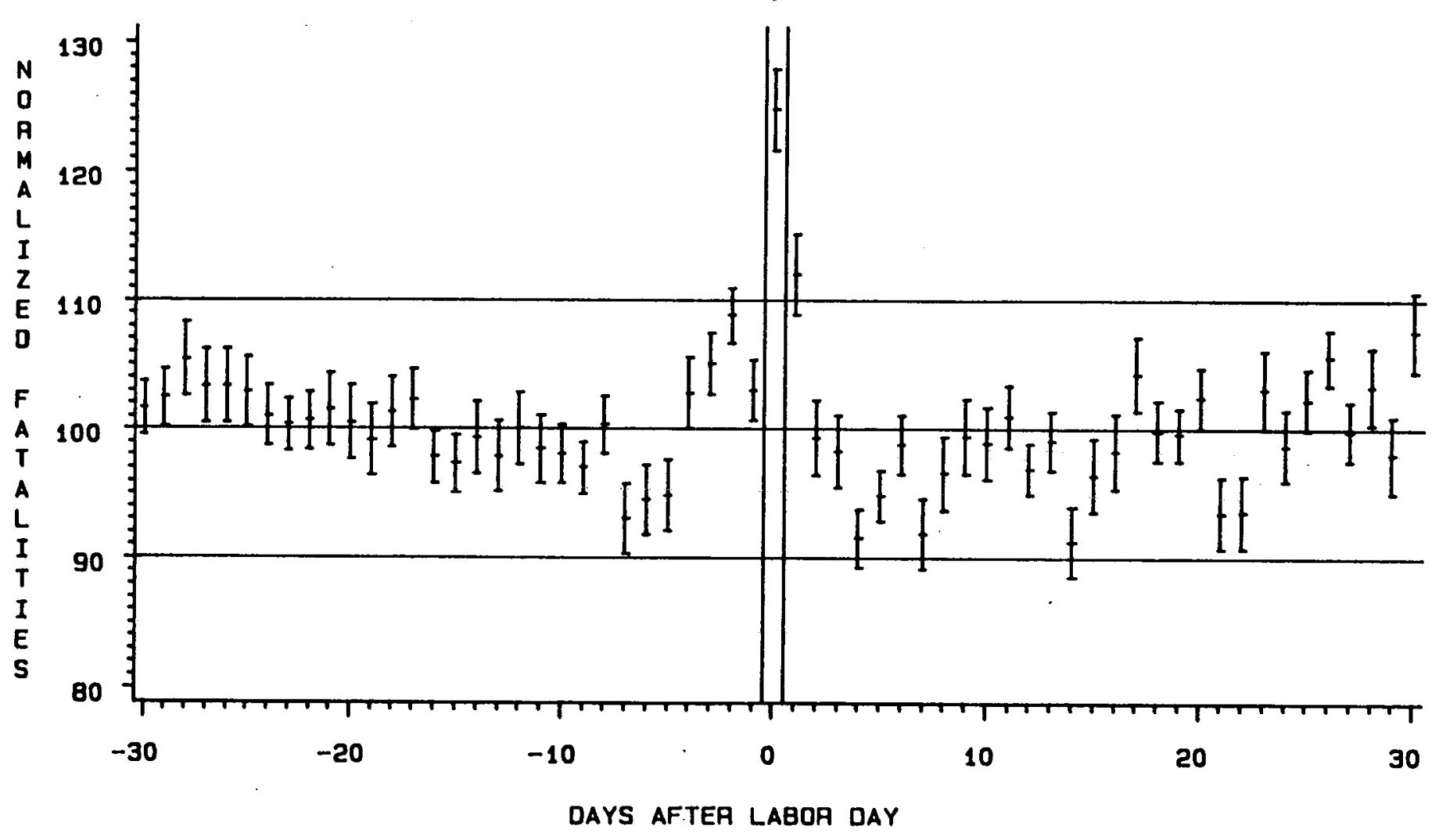

BAR LENGTH IS 2 STANDARD ERRORS 
FIGURE 11

Normalized Fatalities Near Thanksgiving Day Averaged over 1975-85

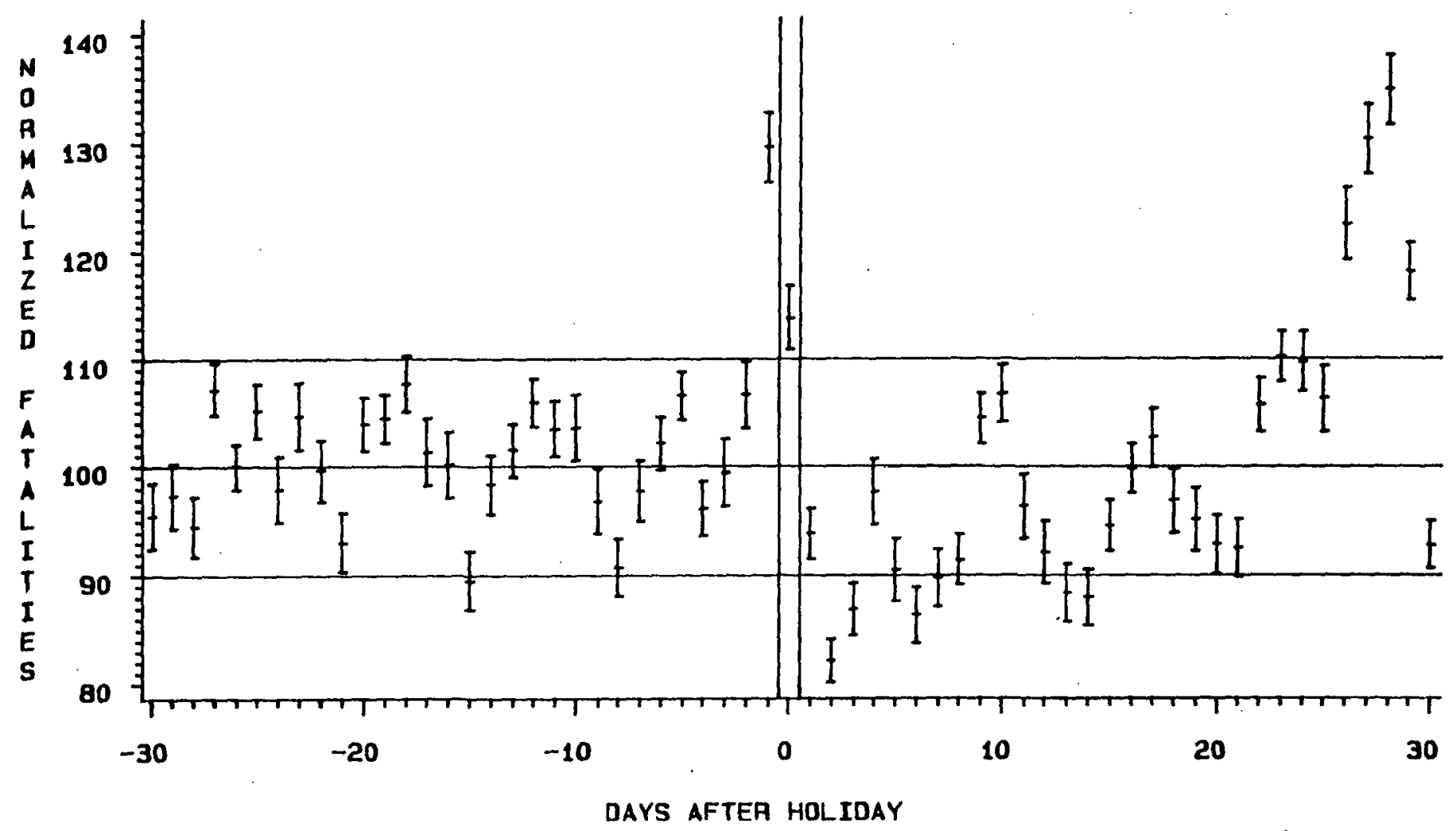

BAR LENGTH IS 2 STANDARD ERRORS 


\section{FIGURE 12}

Normalized Fatalities Near Presidents Day Averaged over 1975-85

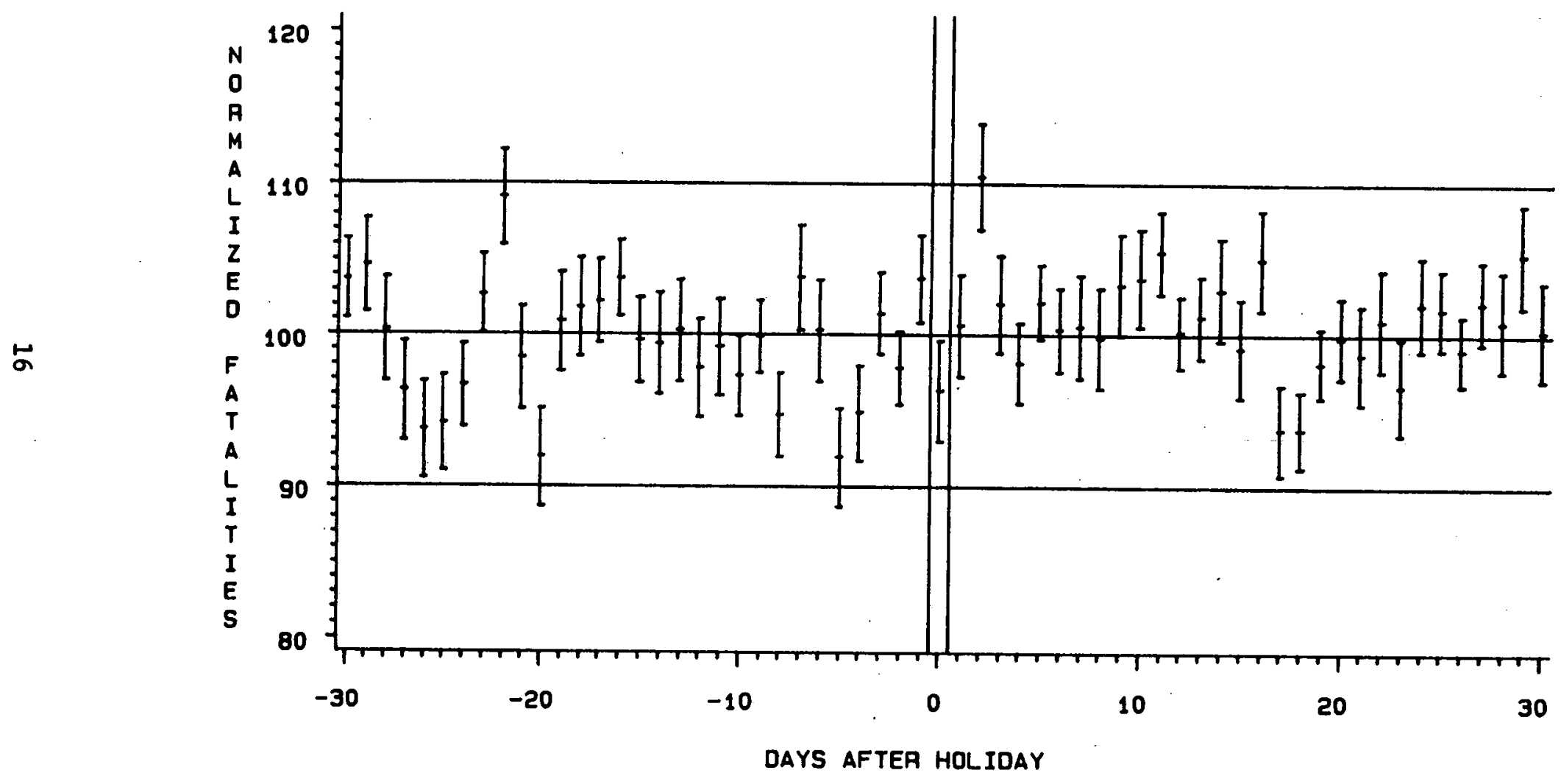

BAR LENGTH IS 2 STANDARO ERROAS 
FIGURE 13

Normalized Fatalities Near Columbus Day

Averaged over 1975-85

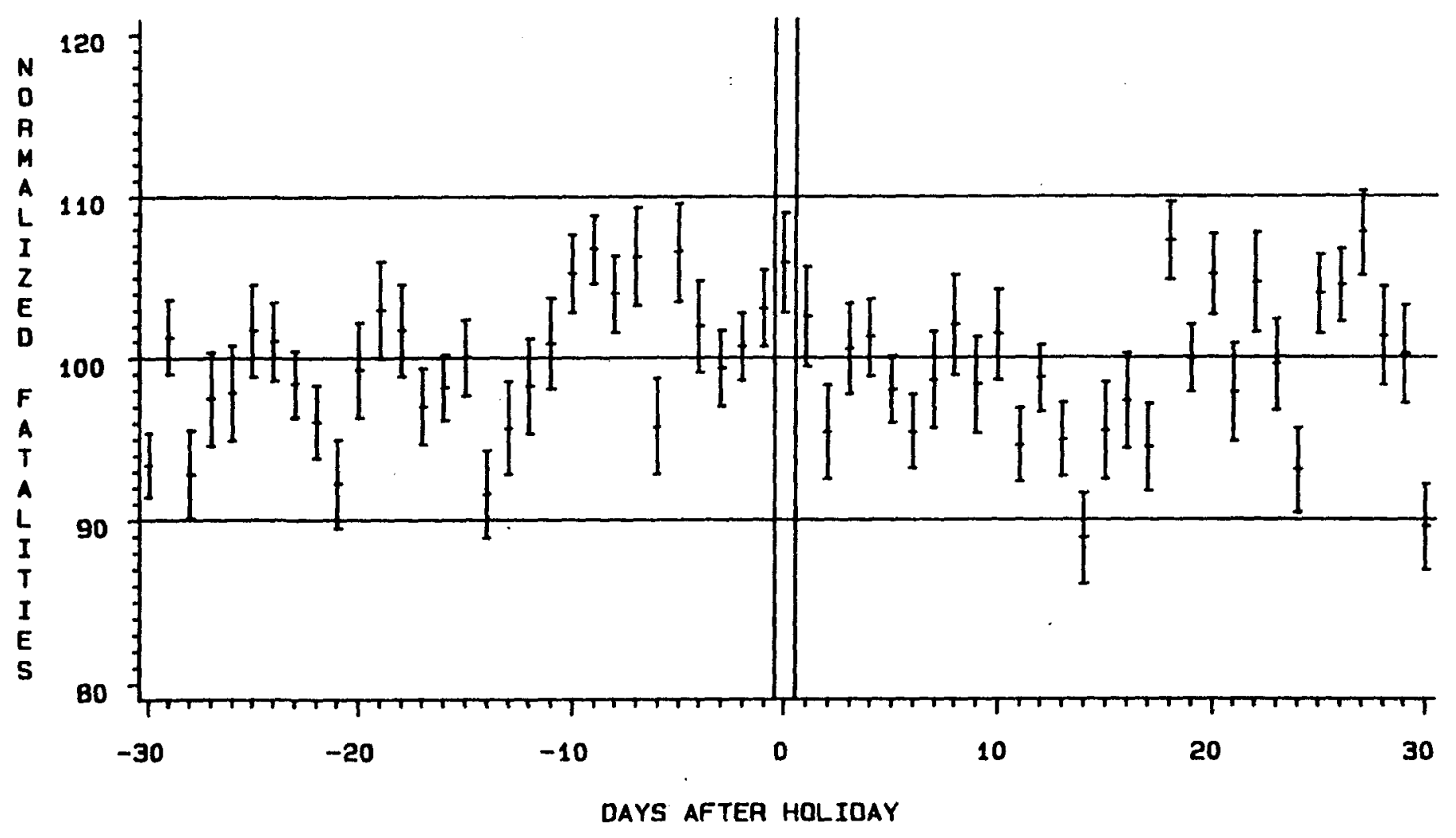

BAR LENGTH IS 2 STANDARD ERRORS 


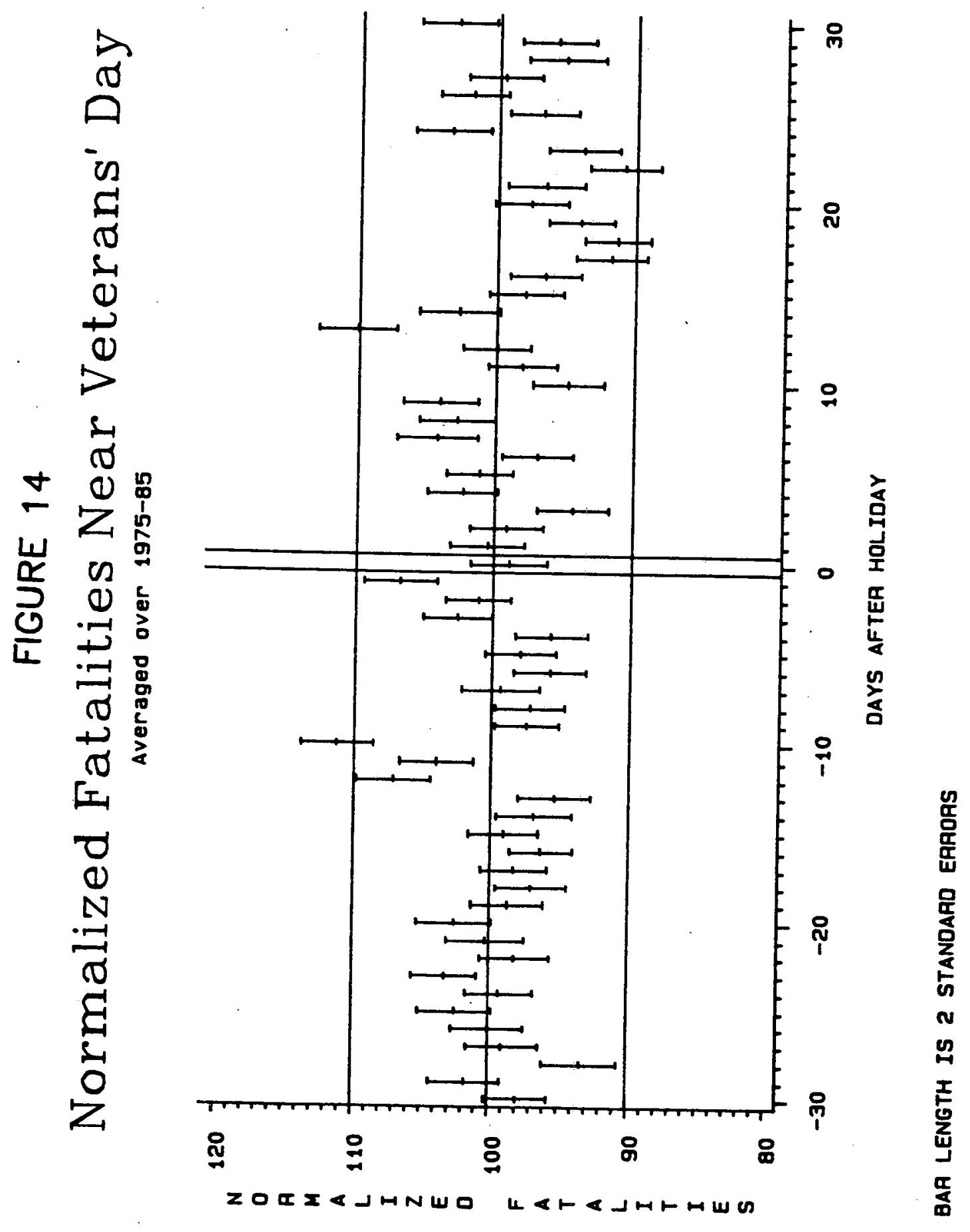


Fiqure 13. The same can be said for Columbus Day, the second Monday in October, except that the day itself is nonsignificantly above 100.

Fiqure 14. Another federal holiday, Veterans Day, was on the fourth Monday in October in 1975-77 and on November 11 in 1978-85 but with Friday or Monday substituted for Saturday or Sunday respectively. The plot of this holiday in Figure 14 shows no interesting features.

\section{Sumnary of Findings:}

This section sumnarizes the traffic fatality effects of each national holiday period. These effects are averages over the entire 11-year period and ay differ from what may happen in a specific year. In addition, these estinates are subject to statistical variation which places a $95 \%$ confidence limit of plus or minus $10 \%$ around each estimate. For example, when a holiday shows an average increase of $40 \%$ the conclusion that can be reached is that it is highly probable that the average increase falls between $30 \%$ and $50 \%$.

No estiate is provided for the Martin Luther King Jr. birthday because no historical data exist for this holiday.

No statistically significant changes occurred during President's Day, Coluabus Day, or Veterans Day.

For Memorial Day the effect on traffic fatalities is linited to the holiday itself and is estinated at a $32 \%$ increase over non-holiday Mondays in May.

The July 4th holiday produces increases for both the 3rd and the 4 th of the wonth which were estinated at $20 \%$ and $37 \%$ respectively.

Labor day reflects an increase of $35 \%$ for the holiday itself and a marginally significant $16 \%$ increase for the day after.

For Thanksgiving, we find that the day before, Wednesday, produces a $42 \%$ increase while for Thanksgiving day the increase was $19 \%$.

The effect over the Christmas holiday is quite singular. First thore is a significant increase during the four days before christmas, followed by significant decreases during the period of the 25 th to the 30 th of December. The increases for the $215 t$ to the 24 th were $18 \%, 29 \%, 40 \%$, and 41\% respectively. The decreases for the 25 th to the 30 th were $11 \%, 18 \%$, $13 \%, 21 \%, 19 \%$, and $15 \%$ respectively. Overall, the increase occurring during the days before Christmas is about twice as large as the decrese shown in the second period.

New Year's Day has the largest effect of any holiday. Fatalities increase by $64 \%$ on New Year's Day itself but are at the normal level on adjacent days. 
Predicting fatalities on a garticular holiday.

The number of fatalities to be expected on a particular holiday can be roughly forecast by using the averages observed during 1975-1985. The forecast is the product of three quantities: the average for that holiday relative to its weekday, the average for that weekday relative to all days of its month, and the expected daily toll for that month relative to its 11-year average. Two examples illustrate the procedure.

The experience of the 11 -years shows that the average Menorial Day produces about $23 \%$ more fatalities than does the average Monday in May. At the same time, the average Monday in May produces about $23 \%$ fewer fatalities than does the average day in May (the 102 average for May Mondays in Table $A$ is $77 \%$ of the 132 average for May in Figure 21. Comparing Memorial day to the rest of May, then, it has about $95 \% 11.23 \times$ $(1-0.23))$ as many fatalities as the daliy average for May.

The dally average for May 1987 can be forecast from a time series model of the monthly fatality history from 1975 up to the latest month available. Such a model accounts for the seasonal variation of fatalities and for the current trend, or underlying level. As of early March 1987, when the most recently available monthly fatality estimate is for January 1987, the time series model forecasts 130 fatalities per day for May 1987. The forecast for Menorial Day is therefore $130 \times 0.95=125$ fatalities. By early May, estimates for February and March will be available so the time series model should more accurately reflect the "current" trend in forecasting May.

A second example is July 4, 1987, which will fall on Saturday. July 4 has averaged $37 \%$ higher than its weekday. Saturdays in July average $43 \%$ higher than all July days 1210 from Table A divided by 147 from figure 2$)$. July 4 fatalities in 1987 are therefore expected to be almost twice 11.43 $x 1.37$ ) the daily average that will be forecast for that month.

These forecasts are subject to considerable uncertainty. An inherent minimun uncertainty arises from forecasting randon events. Expressed as a standard error of the estimate, this uncertainty is equal to the square root of the number of events. For the Memorial Day forecast of 125 fatalities, this would be about 11 , or about $9 \%$ of the estimate. There is also an uncertainty in the factors that are based on 11-year averages and are used in a forecast. The standard error in estimating the average for a particular day of the year is about $4.5 \%$, as was pointed out in the discussion of Figure 6. A one-year estimate has about 3.3 times (square root of (1) the uncertainty of an of 11-year average estimate. This is a 15\% standard deviation in the factor used in the forecast. Comparing observed and predicted holiday fatalities for each year in the eleven-year period shows a standard deviation about the same as the theoretical 15\%. The time series forecast error will generally be 1 ess than $5 \%$ if made only one or two months in advance, and will be swamed by the $15 \%$ error. Taking all this into account, the approximate $95 \%$ confidence band for a holiday prediction will be from $30 \%$ below the prediction to $30 \%$ above. 